\title{
Nitrogen metabolism enzymes activity in flag leaf and roots of pearl millet during grain development stage
}

\author{
MK Berwal, LK Chugh, P Goyal \& R Kumar
}

Journal of Agriculture and Ecology

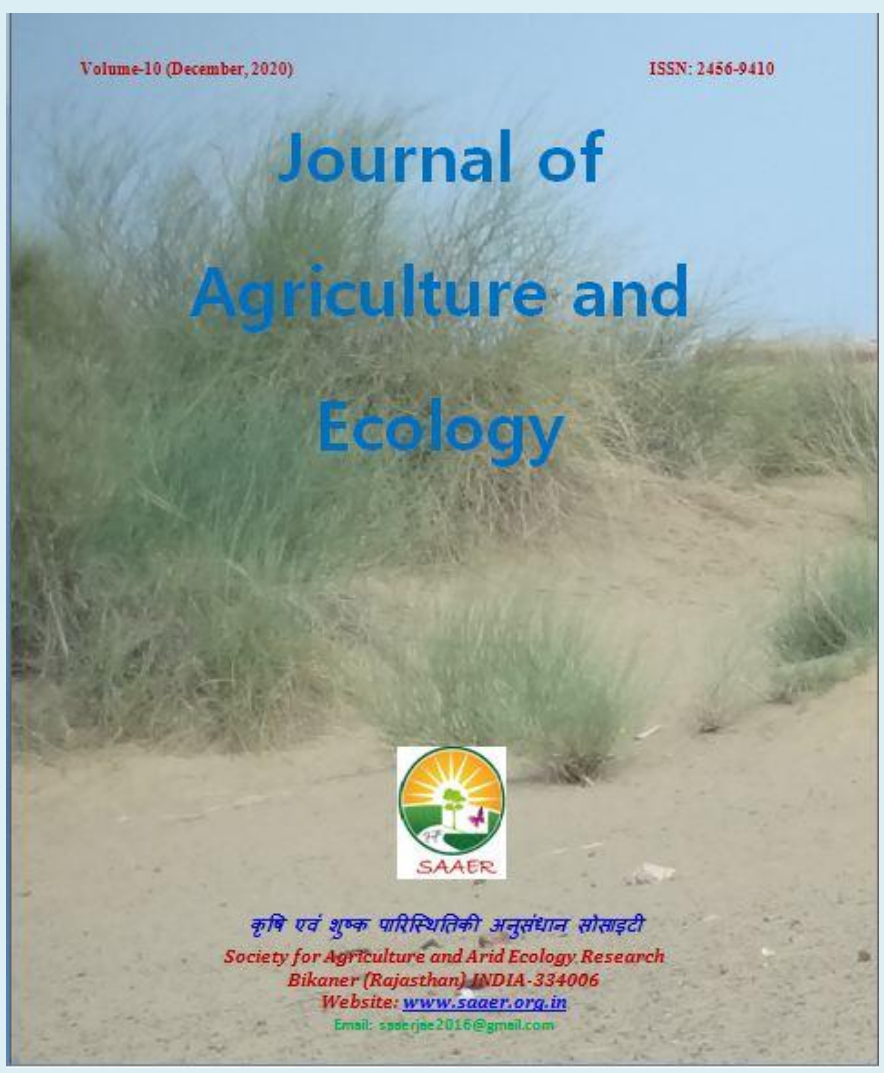

ISSN: 2456-9410

Volume: 10

Journal of Agriculture and Ecology (2020) 10: 44-57 http://doi.org/10.53911/JAE.2020.10204

कि एवं शुष्क पारिस्थितिकी अनुसंधान सोसाइटी Website: www. saaer.org.in 
Nitrogen metabolism enzymes activity in flag leaf and roots of pearl millet during grain development stage

MK Berwal $\varnothing$, LK Chugh ${ }^{1}$, P Goyal $^{1} \& \mathrm{R} \mathrm{Kumar}^{1}$

ICAR-Central Institute for Arid Horticulture, Bikaner-334006

${ }^{1}$ CCS Haryana Agricultural University Hisar-125001

Corresponding author: MK Berwal, E-mail: mkbiochem@gmail.com, mukesh.kumar4@icar.gov.in

Article Info

Article history

Received: 15 October 2020

Accepted: 30 November 2020

Available online: 31 December 2020

Key Words: Pearl millet, nitrogen metabolism enzymes, flag leaf, roots, nitrogen deposition.
Abstract
Nitrate reductase (NR), Glutamine synthatase (GS), Glutamate dehydrogenase (GDH) and Aspartate aminotransaminase (AspAT) were assayed in flag leaves and roots of four pearl millet genotypes, started from ear emergence till grain maturity at four days intervals. All enzymes showed higher activities in flag leaf than that of roots irrespective of growth stage and genotypes. A slight increase in flag leaf NR, GS and AspAT activity till anthesis started decreasing while GDH increased till 12 days after anthesis (DAA) and almost constant till 18 DAA and then started decreasing. While in roots a steep declining trend was observed in NR, GS and AspAT and reached to almost non-detectable level till maturity while GDH increased up to 6 DAA and then decreased sharply irrespective of the genotypes. The almost stable GDH activity and decreasing trend in NR, GS and AspAT suggested that re-assimilation of amino nitrogen takes place in flag leaf instead of direct assimilation from the roots for nitrogen deposition in pearl millet developing grains.

Copyright (C2020 Berwal et al., This is an open access article published under the terms of the Creative Commons Attribution License, which permits unrestricted use, distribution, and reproduction in any medium, provided the original work is properly cited.

Preferred citation: Berwal MK, Chugh LK, Goyal P and Kumar R. 2020. Nitrogen metabolism enzymes activity in flag leaf and roots of pearl millet during grain development stage. Journal of Agriculture and Ecology, 10: 44-57; http://doi.org/10.53911/JAE.2020.10204.

\section{Introduction}

Nitrogen metabolism is not only one of the basic processes of plant physiology, but also one of the important parts of global chemical cycle. Plant nitrogen assimilation directly takes part in the synthesis and conversion of amino acid through the reduction of nitrate. During this stage, some key enzymes, e.g., nitrate reductase (NR), glutamine synthetase (GS), glutamate dehydrogenase (GDH), glutamine synthase (GOGAT), aspargine synthetase (AS), and asparate aminotransferase (AspAT) participate in these processes. Nitrate is reduced to $\mathrm{NH}^{+}$ by sequential action of nitrate reductase (NR) and nitrite reductase (NiR). The conversion of $\mathrm{NH}_{4}{ }^{+}$into glutamate proceeds via two pathways. In the GS/GOGAT pathway, $\mathrm{NH}^{+}$ is incorporated into glutamine by glutamine synthetase (GS), which is then converted with 
2-oxoglutarate (2-OG) to glutamate by glutamate synthase (GOGAT). Glutamate dehydrogenase (GDH) catalyzes the incorporation of $\mathrm{NH}_{4}^{+}$into glutamate by reversible reductive amination of 2-OG (Inokuchi \& Okada 2001; Cruz et al. 2004).

The cytosolic NR is the first enzyme in the pathway of nitrate assimilation, and its activity is highly regulated. Sufficient NR activity is a prerequisite for optimal utilization of soil nitrogen. NR has a major role in incorporation of nitrogen for plant yields under field conditions and it is widely known to be substrate inducible (Bergareche \& Simon 1988). This is a rate limiting enzyme in the series of reactions whereby nitrogen is utilized for protein synthesis by plants and is known to be influenced by available soil nitrogen, the amount of light, environmental factors and genetic composition of plant (Ingle et. al. 1966; Kannangara et. al. 1967; Duffield et. al. 1972). Gupta et al. (2012) and Liyuan and Shi (2013) reported a positive response of NR activity in flag leaf after anthesis with nitrogenous fertilizer application in finger millet and winter wheat respectively. Similarly, Liyuan \& Shi (2013) reported in winter wheat that soluble protein and nitrate reductase activity was very high at the beginning of the anthesis in flag leaf. However, flag leaf soluble protein content and NR activity continued to decrease in 7 days after anthesis and decreased rapidly in 14 days after anthesis under all treatments. Gupta et al. (2012) observed that the low grain protein genotypes reported higher NR in flag leaf at grain filling stage having better nitrogen use efficiency and responded well under higher nitrogen condition and its flag leaf was greener till maturity than that of high grain protein containing genotypes. The sequential decrease in NR during flowering and grain filling stages, in white and golden genotypes quickly transported the nitrogen from early stages of grain filling which continued till the end of grain filling.

After nitrate reduction, GS is the key enzyme responsible for the assimilation and re-assimilation of ammonia. In higher plants GS is one of the major enzymes responsible for the assimilation of ammonium absorbed from the growth medium, generated by nitrate reduction or re-assimilated after release of endogenous $\mathrm{NH}_{4}{ }^{+}$by ammonium evolving processes such as photorespiration (Lea \& Miflin 1974; Fentem et al. 1983; Claussen \& Lenz 1999; Berwal et al. 2018). GDH is one of the few enzymes capable of releasing amino nitrogen from amino acids to give a keto-acid and $\mathrm{NH}_{3}$ that can be separately recycled to be used in respiration and amide formation, respectively (Miflin \& Habas 2002). GDH is expected to function in the deaminating direction in tissues (germinating seeds and senescing leaves) that are converting amino acids into transport compounds with a low $\mathrm{C} / \mathrm{N}$ ratio (Aubert et. al. 2001, Goyal et al. 2017). Srivastava \& Singh (1987) reported that GDH level increased under various stressed conditions because plant may well need to give priority to carbon metabolism and keto-acid production over nitrogen metabolism. Many researchers observed an inhibited plant growth under stressed conditions in GDH null mutants in maize (Magalhaes et al. 1990; Pryor 1990) and in Arabodopsis thaliana (Melo-Olivera et al. 1996). It would happen 
because GDH null mutants would be unable to convert glutamate to $\mathrm{NH} 3$, glutamine and oxoglutarate (Stewart et al. 1995). Liyuan \& Shi (2013) found in winter wheat that GS activity was very high at the beginning of the anthesis in flag leaf. However, flag leaf GS activity continued to decrease in 7 days after anthesis and decreased rapidly after 21 days after anthesis under all treatments. Flag leaf GS activities increased with increasing amount of nitrogen application. It indicated that nitrogen fertilization improves the leaf NR and GS activity as well as leaf soluble protein content. Kichey et al. (2009) also observed similar results for GS and GDH with ageing flag leaf of wheat. Gupta et al. (2012) observed that the low grain protein (brown) showed higher GDH activity and lower GS activity in flag leaf at grain filling stage having better nitrogen use efficiency and responded well under higher nitrogen condition and its flag leaf was greener till maturity than that of high grain protein containing genotypes (Golden and Brown). The sequential increase in the activity of GDH and later GS during flowering and grain filling stages, respectively, in white and golden genotypes quickly transported the nitrogen from early stages of grain filling which continued till the end of grain filling. This might be a reason for high grain protein content in the white and golden genotypes. Contrastingly, in case of the brown genotype (low grain protein), GDH activity in the flag leaves was also found to be increased and it remained high till the grain filling stage. It indicates that both high GS activity along with high GDH activity is probably necessary at the time of flowering to grain filling to carry out the de-amination and transamination reactions during hydrolysis of flag leaves chloroplast initiated at the time of flowering.

Yong-Jian et al. (2009) had observed in rice flag leaves that GS activity increased from tillering stage to heading stages and started decreasing towards maturity stage at all irrigation and nitrogen fertilizer treatments. They observed that there were positive correlation between grain nitrogen content and functional leaves NR, GS and GOGAT enzymatic activities with the maximum correlation coefficient at heading stage, and also observed significant positive correlation between total nitrogen accumulation (TNA) and grain yield with activities of NR, GS and GOGAT at various growth stages except for tillering stage, this correlation was more closer with TNA than grain yield. Aspartate biosynthesis is mediated by the enzyme aspartate aminotransferase (AspAT; aspartate: 2-oxoglutarate aminotransferase; EC 2.6.1.1) which catalyses the reversible transamination between glutamate and oxaloacetate to generate aspartate and 2-oxoglutarate via a ping-pong bi-bi kinetic mechanism. The enzyme plays a key role in the metabolic regulation of $\mathrm{C}$ and $\mathrm{N}$ metabolism in all organisms. Nitrogen $(\mathrm{N})$ is incorporated into carbon skeletons for the biosynthesis of the primary amino acids, glutamine and glutamate, which serve as $\mathrm{N}$ donors for the biosynthesis of major $\mathrm{N}$ compounds in plants, including other amino acids, nucleic acid bases, polyamines, and chlorophylls (Torre et. al. 2014). Under anaerobic condition i.e. under stressed conditions, accumulation of pyruvate leads to the alanine biosynthesis by upregulating the enzyme alanine 
aminitransferase in plants (Streeter \& Thompson 1972; Stewart \& Larher 1980). Sempruch et al. (2012), observed under biotic stress (aphid feeding) which caused an increase in AlaAT activity and a decrease in AspAT with in tissues of winter triticale. Diestelfeld (2007) has reported a positive relationship between grain protein and $\mathrm{Zn}$ accumulation in wheat grain. No report is available in literature on pearl millet about such relationship. Keeping this view in mind the present experiment was designed to elucidate trend of nitrogen metabolism enzymes activity in flag leaf and roots of pearl millet during grain filling stage.

\section{Materials and Methods}

The present investigation was conducted with four pearl millet genotypes viz. HMS 14B, HMS 53B, HC 20 and WHC 901-445. The selected pearl millet genotypes were raised in 10 rows each with $10 \times 45 \mathrm{~cm}$ intra and inter row spacing following the standared package and practices at research farm CCS HAU, Hisar during kharif-2014. Before growing of crop as well as after harvesting of crop, the Fe and $\mathrm{Zn}$ status of soil was determined. Four random soil samples were collected from each plot and mixed them properly to make it representative sample of the respective plots. The Fe content varied from 4.5 to $7 \mathrm{mg} / \mathrm{kg}$ and $\mathrm{Zn}$ content varied from 0.6 to $1.7 \mathrm{mg} / \mathrm{kg}$. No significant variation was observed in $\mathrm{Fe}$ and $\mathrm{Zn}$ content before sowing and after harvesting of the crop.

The sampling time was fixed between 10.00 to 11.00 am in full sunshine. The plants were tagged on ear emergence and samples (flag leaf and roots) were collected on 25 days before anthesis (DBA) and 5 DBA, 0 DAA (days after anthesis) and on every forth day starting 12 DAA till 28 DAA and activities of nitrogen metabolism enzymes viz. NR, GS, GDH and AspAT were determined with following the standard protocols.

\section{Nitrate reductase (NR) (E.C. 1.6.6.1)}

In-vivo Nitrate reductase was determined using procedure of Sawhney and Naik (1972). The enzyme was assayed colorimetrically by monitoring the amount of nitrite produced. For determining in-vivo activity of nitrate reductase, $250 \mathrm{mg}$ leaf discs were suspended in $10 \mathrm{ml}$ of a medium constituting $50 \mathrm{mM}$ phosphate buffer $(\mathrm{pH}$ 7.5), $20 \mathrm{mM} \mathrm{KNO}_{3}$ and 3\% (v/v) n-propanol and then vacuum infiltrated till all the discs sank to the bottom of solution. These tubes were incubated in dark in an incubator at $30^{\circ}$ C. After 0,10 and $30 \mathrm{~min}, 1 / 10$ of aliquot was withdrawn and the amount of $\mathrm{NO}_{2}^{-}$released was estimated by the method described by Fewson and Nicholas (1961). To $2 \mathrm{ml}$ of properly diluted aliquot, $1 \mathrm{ml}$ of $1 \%(\mathrm{w} / \mathrm{v})$ sulfanilamide solution (prepared in 1N HCL) was added, the contents mixed thoroughly and then the colour developed with $1 \mathrm{ml}$ of $0.02 \%$ (w/v) 1-Naphthyl ethylenediamine dihydrochloride (NED). The absorbance was recorded after 30 minutes on a UV-Vis spectrophotometer (Thermo Scientific, EVOLUTION 201) at $540 \mathrm{~nm}$. The amount of nitrite was determined from the standard curve prepared with sodium nitrite (20-100 nmoles). The results of NR activities were expressed as $\mu$ moles of $\mathrm{NO}_{2}{ }^{-}$formed $\mathrm{h}^{-1} \mathrm{~g}^{-1}$ fresh weight.

\section{Glutamine dynthetase (E.C.6.3.1.2)}

The activity of glutamine synthetase (transferase activity) was assayed colorimetrically by estimation the amount of 
$\square$-glutamyl monohydroxamate ( $\square$-GMH) produced according to the method of Kanamori and Matsumoto (1972). The plant tissues were extracted in $0.1 \mathrm{M}$ phosphate buffer $\quad(\mathrm{pH} \quad 7.6) \quad$ containing $2 \%$ polyvinylpyrrolidone (PVP), $1 \% \quad \beta$ mercaptoethanol and $10 \mathrm{mM}$ dithiothreitol (DTT). Reaction mixture for assaying the enzyme activity, in the final volume of $2 \mathrm{ml}$, containing in $\mu$ moles: Tris- $\mathrm{HCl}$ buffer $(\mathrm{pH}$ 7.2), 150; glutamine, 150; hydroxylamine hydrochloride (neutralized), 70; ADP, 1.2; sodium arsenate, $80 ; \mathrm{MnCl}_{2}, 1.5$ and enzyme extract. Hydroxylamine was omitted from the blank. The tubes were incubated at $27{ }^{0} \mathrm{C}$ for 30 minutes and then the reaction was stopped by adding $2 \mathrm{ml}$ of stop mixture containing 4 $\mathrm{ml}$ of $10 \% \mathrm{FeCl}_{3}, 1 \mathrm{ml}$ of $24 \%$ TCA, $0.5 \mathrm{ml}$ of $6 \mathrm{~N} \mathrm{HCl}$ and $6.5 \mathrm{ml}$ of distilled water. After 10 min, the protein precipitate was removed by centrifugation. The hydroxamic acid formed in the supernatant was measured on a UV-Vis spectrophotometer (Thermo Scientific, EVOLUTION 201) at $540 \mathrm{~nm}$ and its concentration was computed using -glutamyl monohydroxamate (-GMH) as standard (0.5 to $4 \mu$ moles) (Annexure I, fig. M5). The results were expressed as $\mu$ moles of -GMH formed $h^{-}$ ${ }^{1} \mathrm{~g}^{-1}$ fresh weight.

\section{Glutamate dehydrogenase (E.C.1.4.1.3)}

Glutamate dehydrogenase (GDH) activity was assayed spectrophotometrically at $340 \mathrm{~nm}$ by following oxidation of NADH according to the method of Murrey and Kennedy (1980). The plant tissues were extracted in $0.1 \mathrm{M}$ phosphate buffer ( $\mathrm{pH}$ 7.6) containing 2\% polyvinylpyrrolidone (PVP), $1 \% \quad \beta$-mercaptoethanol and $10 \quad \mathrm{mM}$ dithiothreitol (DTT). The reaction mixture, in a final volume of $3 \mathrm{ml}$, contained in $\mu$ moles: phosphate buffer ( $\mathrm{pH}$ 7.5), 120; $\alpha$ ketoglutarate, 18; ammonium sulphate, 150; NADH 0.4 and enzyme preparation. Rate of the reaction was followed by recording the change in absorbance at $340 \mathrm{~nm}$ in a UV-Vis spectrophotometer (Thermo Scientific, EVOLUTION 201). Background rates were also measured in the absence of $\alpha$ ketoglutarate. The enzyme activity was expressed as $\mu$ moles NADH $\mathrm{h}^{-1} \mathrm{~g}^{-1}$ fresh weight.

\section{Aspartate aminotransferase (EC 2.6.6.1)}

Aspartate aminotransferase was assayed by following the method of Murrey and Kennedy, (1980). The plant tissues were extracted in $0.1 \mathrm{M}$ phosphate buffer ( $\mathrm{pH}$ 7.6) containing 2\% polyvinylpyrrolidone (PVP), $1 \% \quad \beta$-mercaptoethanol and $10 \quad \mathrm{mM}$ dithiothreitol (DTT). The reaction mixture, in a final volume of $3 \mathrm{ml}$, contained in $\mu$ moles: phosphate buffer $(\mathrm{pH}$ 7.5), 120; $\alpha$ ketoglutarate, 18; L-aspartate, 30; malate dehydrogenase, 3 IU; NADH 0.4 and appropriate volume of enzyme preparation. The reaction was started with $\alpha$-ketoglutarate. Rate of the reaction was followed by recording the change in absorbance at $340 \mathrm{~nm}$ in a UV-Vis spectrophotometer (Thermo Scientific, EVOLUTION 201). Background rates were also measured in the absence of $\alpha$ ketoglutarate. The enzyme activity was expressed as $\mu$ moles NADH h-1 g-1 fresh weight.

\section{Results and Discussions}

The results of the nitrogen metabolism enzymes activity in flag leaf and roots during grain filling stage are described here.

In vivo nitrate reductase (NR) 
NR activity (in vivo) of the five pearl millet genotypes mentioned above was determined in flag leaf and roots at different plant growth stages indicated earlier. Profile of change in the activity of nitrate reductase in flag leaf and roots is depicted in figures $1 \&$ table 1. Magnitude of in vivo NR activity assayed at vegetative stage of growth on 25 DBA in flag leaf of the five genotypes was significantly different. Among the designated B-lines maximum activity was present in the leaf of HMS 14B (13.9 $\mu$ moles $\left.\mathrm{NO}_{2}^{-} \mathrm{g}^{-1} \mathrm{~h}^{-1}\right)$ followed by HMS 53B (7.16 $\mu$ moles $\mathrm{NO}_{2}{ }^{-} \mathrm{g}^{-}$ ${ }^{1} \mathrm{~h}^{-1}$ ) while in vivo NR activity of $\mathrm{HC} 20$ and WHC 901-445 was closer to that of HMS 53B. The enzyme activity increased linearly in all the five genotypes till 0 DAA and reached at maximum level. After the start of anthesis activity of NR started declining in all the genotypes. Except in WHC 901-445, the enzyme activity decreased almost linearly till 20 DAA, to a level much lower compared to that was observed at the start of flowering. Decline in the enzyme activity in WHC 901445 was very sharp. For example the activity in flag leaf of MHS 14B declined from 17.35 to $12.46 \mu$ moles $\mathrm{NO}_{2}^{-} \mathrm{g}^{-1} \mathrm{~h}^{-1}$ between 0 and 16 DAA while that of WHC 901-445 declined from 13.47 to 4.50 umoles $\mathrm{NO}_{2}^{-} \mathrm{g}^{-1} \mathrm{~h}^{-1}$ between the corresponding period. By 28 DAA activity of HMS 53B, HC 20 and WHC 901-445 fell to a minimum level of about 2 $\mu$ moles $\mathrm{NO}_{2}^{-} \mathrm{g}^{-1} \mathrm{~h}^{-1}$ while that of HMS 14B remained about two fold higher than that of the other genotypes.
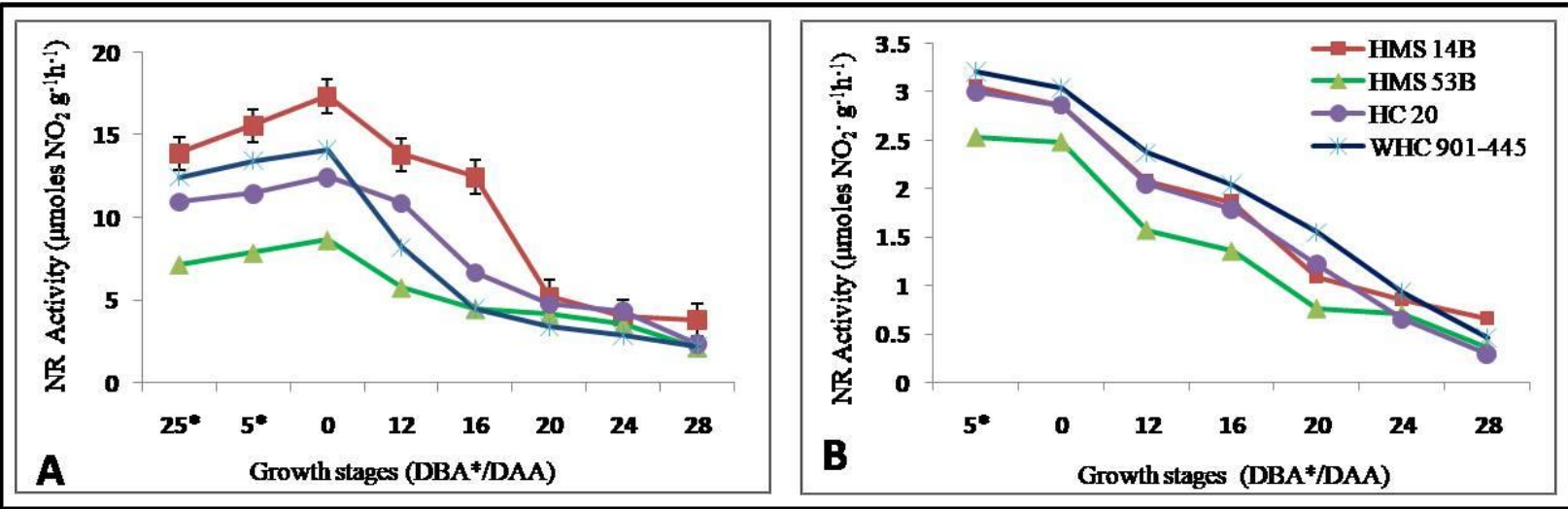

Fig 1. Nitrate reductase (NR) activity $\left(\mu \mathrm{g} \mathrm{NO}{ }_{2}^{-} \mathrm{g}^{-1} \mathrm{~h}^{-1}\right)$ in Pearl millet genotypes during grain filling stages A. Flag leaf B. Roots. (*DBA-days before anthesis/DAA-days after anthesis)

Table 1. Nitrate reductase (NR) Activity ( $\mu$ moles $\mathrm{NO}_{2}^{-} \mathrm{g}^{-1} \mathrm{~h}^{-1}$ ) in flag leaf of pearl millet at different growth stages

\begin{tabular}{ccccc}
\hline Growth & HMS & HMS & HC & WHC \\
\hline 25 DBA & 13.90 & 7.16 & 10.9 & 12.47 \\
5 DBA & 15.57 & 7.87 & 11.4 & 14.14 \\
0 DAA & 17.35 & 8.65 & 12.4 & 13.47 \\
12 DAA & 13.81 & 5.75 & 10.8 & 8.20 \\
16 DAA & 12.46 & 4.45 & 6.67 & 4.50 \\
20 DAA & 5.24 & 4.12 & 4.78 & 3.40
\end{tabular}

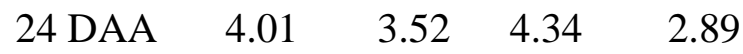

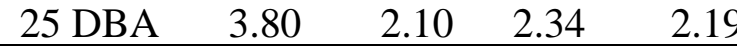

Table 2. Nitrate reductase (NR) Activity ( $\mu$ moles NO2- g-1h-1) in roots of pearl millet at different growth stages

\begin{tabular}{ccccc}
\hline Grow & HMS & HMS & HC & WHC \\
\hline 5 & 3.05 & 2.53 & 3 & 3.21 \\
0 & 2.85 & 2.48 & 2.86 & 3.04 \\
12 & 2.08 & 1.57 & 2.05 & 2.37 \\
16 & 1.86 & 1.35 & 1.79 & 2.04
\end{tabular}


Glutamine synthetase (GS)

Glutamine synthetase (GS) activity of above mentioned pearl millet genotypes was also monitored in flag leaf and roots starting from 25 days before anthesis (DBA) till maturity i.e. 28 days after anthesis (DAA) at the indicated time intervals (Fig. 2 \& table 3, 4). Level of GS activity on 25 DBA in flag leaf of the tested genotypes was as follows: HMS 14B (697 $\mu$ moles -GMH g $\left.{ }^{-1} \mathrm{~h}^{-1}\right)$, HMS 53B (309 $\mu$ moles -GMH g $\left.{ }^{-1} \mathrm{~h}^{-1}\right)$, HC 20 (425 $\mu$ moles -GMH g $\left.{ }^{-1} h^{-1}\right)$ and WHC 901-445 (377 $\mu$ moles -GMH g ${ }^{-1} \mathrm{~h}^{-1}$ ). less similar in respect of the level of activity.
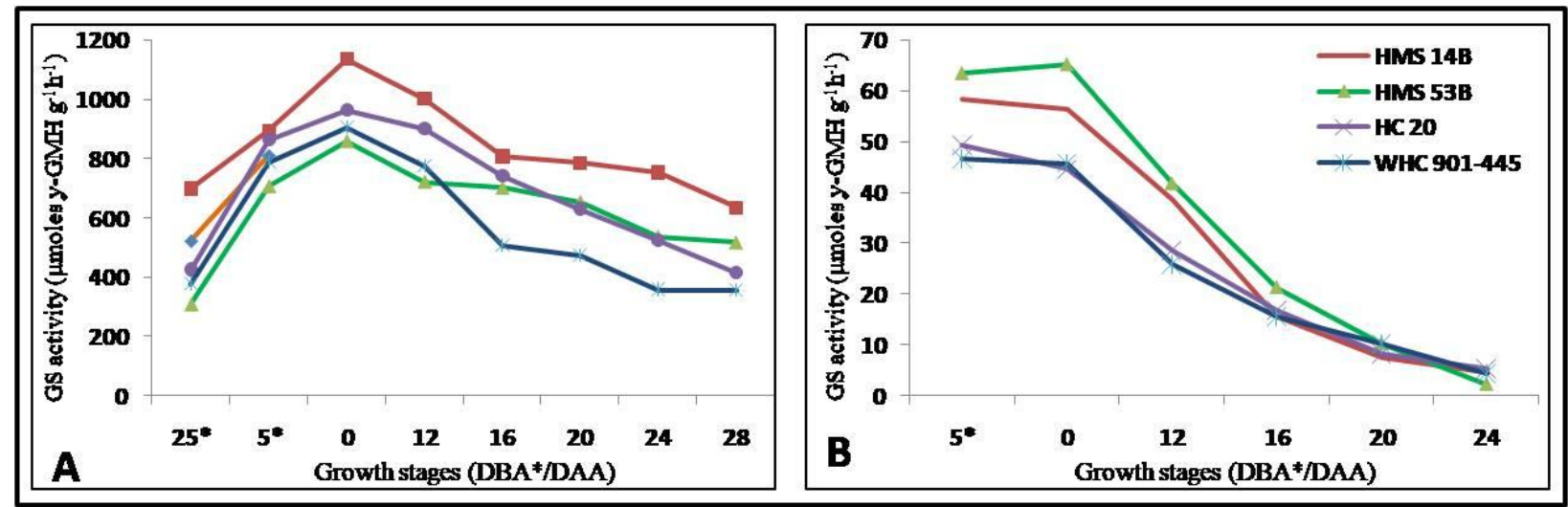

Fig 2. Glutamine synthetase (GS) activity ( $\mu$ moles $\Upsilon-\mathrm{GMH} \mathrm{g} \mathrm{g}^{-1} \mathrm{~h}^{-1}$ ) in pearl millet during grain filling stages A. Flag leaf B. Roots. (*DBA-days before anthesis/DAA-days after anthesis)

Table 3. Glutamine synthetase (GS) activity ( $\mu$ moles gamma-GMH g ${ }^{-1} h^{-1}$ ) in flag leaf of pearl millet at different growth stages

\begin{tabular}{ccccc}
\hline Grow & HMS & HMS & HC & WHC \\
\hline 25 & 697 & 309 & 425 & 377 \\
5 & 893 & 707 & 863 & 789 \\
0 & 1135 & 859 & 964 & 905 \\
12 & 1002 & 722 & 901 & 775 \\
16 & 806 & 702 & 741 & 507 \\
20 & 784 & 654 & 631 & 474 \\
24 & 752 & 538 & 524 & 357 \\
25 & 634 & 518 & 415 & 356 \\
\hline
\end{tabular}

Thus GS activity of the genotypes differed markedly among all the genotypes on 25DBA.
GS activity was maximum in HMS 14B. Like $\mathrm{NR}$, activity of this enzyme on the same day of plant growth in HMS 53B was lowest among the other genotypes. Level of activity of NR and GS in leaves of HC 20 and WHC 901-445 was contrasting, i.e. activity of NR was higher with lower level of GS activity in WHC 901-445 (compared to HC 20) whereas activity of NR was lower with a higher level of GS activity in HC 20. Activity of GS increased sharply along with growth of the plants till start of anthesis in each genotype but differentially and attained maximum level 
in each genotype. For example, the enzyme activity increased by a maximum of more than two fold from $377 \mu$ moles $\square-G M H g^{-1} h^{-1}$ to $905 \mu$ moles $\square$-GMH g ${ }^{-1} \mathrm{~h}^{-1}$ in WHC 901-445 whereas, in HMS 14B the enzyme activity increased from $697 \mu$ moles gamma-GMH g${ }^{1} \mathrm{~h}^{-1}$ to $1135 \mu$ moles $\square$-GMH g ${ }^{-1} \mathrm{~h}^{-1}$. Except WHC 901-445, GS activity in the other genotypes declined sharply till 16 DAA and then gradually and reached to a minimum level by 28 DAA. On the last day GS activity in flag leaf of HMS 14B remained much higher than that of the other genotypes and on the last day, (28 DAA) of the sampling WHC 901-445 showed the least activity.

Table 4. Glutamine synthetase (GS) activity ( $\mu$ moles gamma-GMH g ${ }^{-1} h^{-1}$ ) in roots of pearl millet at different growth stages.

\begin{tabular}{ccccc}
\hline Grow & HMS & HMS & HC & WHC \\
\hline 5 & 58.23 & 63.36 & 49.2 & 46.64 \\
0 & 56.32 & 65.12 & 44.5 & 45.76 \\
12 & 38.48 & 41.66 & 28.5 & 25.83 \\
16 & 15.55 & 21.27 & 16.8 & 15.59 \\
20 & 7.58 & 10.25 & 8.23 & 10.215 \\
24 & 4.55 & 2.21 & 5.32 & 4.25 \\
25 & ND & ND & ND & ND \\
\hline
\end{tabular}

Trend in changes in the activity of GS in roots of the pearl millet designated B-lines HMS 14B and HMS 53B and composites HC 20 and WHC 901-445 since vegetative stage starting 5 DBA till maturity is presented in figure $2 \mathrm{~B} \&$ table 4 . The enzyme activity in root of each genotype analyzed on 5BDA was lower (ranging from $1 / 5^{\text {th }}$ to $1 / 10^{\text {th }}$ ) compared to that of flag leaf of the respective genotype. The level of activity observed on 5 DBA was maintained till stage of the anthesis by each genotype. A drastic reduction in the activity in roots of all the genotypes was recorded between 0 DAA and 16 DAA. And the enzyme remained minimal active and statistically similar in roots of all the genotypes on 20 DAA and 24DAA.

\section{Glutamate dehydrogenase (GDH)}

Figure 3 A \& B shows pattern of change in activity of GDH in flag leaf and roots of five pearl millet genotypes. Like NR, $\mathrm{NiR}$ and GS, activity of GDH in flag leaf was higher than that of roots of all the genotypes during the entire growth period. GDH activity in flag leaf showed increasing trend during vegetative stage starting 25 DBA till start of anthesis i.e. 0 DAA (Fig. 3A \& table 5) and in roots starting 5 DBA till 0 DAA (Fig. 3B \& table 6). In general, level of GDH activity in flag leaf assayed on a particular day during the period between 0 and 20 DAA of HMS 14B, HMS 53B, HC 20 and WHC 901-445 remained either almost constant or decreased slightly.

Table 5. Glutamate Dehydrogenase (GDH) activity $\left(\mu\right.$ mole NADH $\mathrm{g}^{-1} \mathrm{~h}^{-1}$ ) in flag leaf of pearl millet at different growth stages

\begin{tabular}{ccccc}
\hline Grow & HMS & HMS & HC & WHC \\
\hline 25 & 71.3 & 47.5 & 95.0 & 58.1 \\
5 & 90.8 & 56.1 & 103. & 72.6 \\
0 & 101.6 & 72.6 & 107. & 98.0 \\
12 & 111.6 & 75.0 & 105. & 94.9 \\
16 & 104.6 & 73.0 & 98.0 & 80.5 \\
20 & 101.0 & 64.7 & 78.0 & 78.0 \\
24 & 81.8 & 59.4 & 73.0 & 73.0 \\
25 & 75.5 & 56.8 & 60.7 & 72.6 \\
\hline
\end{tabular}

For example the activity in flag leaf varied between 101 to $112 \mu$ moles NADH g${ }^{1} \mathrm{~h}^{-1}$ in HMS 14B and between 65 to $75 \mu$ moles NADH $\mathrm{g}^{-1} \mathrm{~h}^{-1}$ in HMS 53B during the reproductive period of 20 days, starting 0 DAA. After slow and gradual decrease in activity of the enzyme after 20 DAA, a substantial amount of enzyme remained active 
on 28 DAA ranging from 57 to $76 \mu$ moles NADH $\mathrm{g}^{-1} \mathrm{~h}^{-1}$. From the pictorial presentation of data in fig. $3 \mathrm{~A}$, it is also clear that GHD activity in flag leaf during the entire reproductive period in respective genotype remained higher than the initial level of its activity recorded at 25 DBA. In contrast GDH

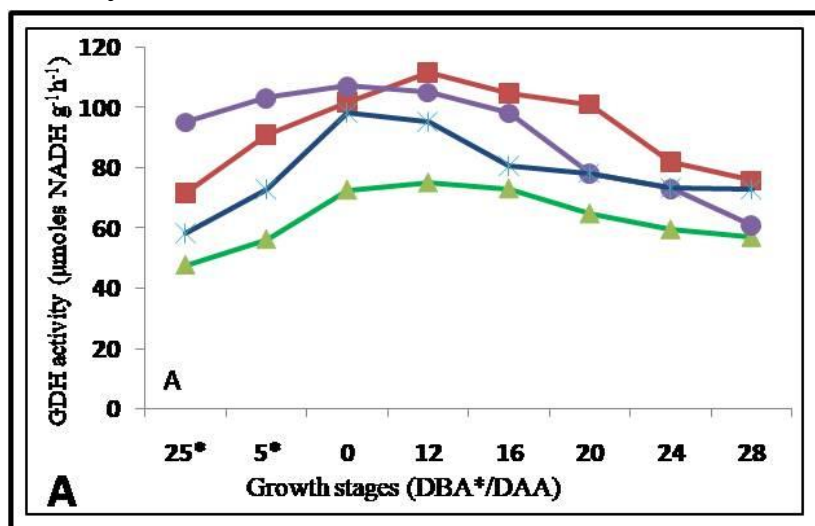

activity in roots decreased sharply starting from 12 DAA and only trace of the enzyme remained active by $24^{\text {th }}$ day of anthesis (Fig. 3B). Thus in flag leaf a significant level of GDH activity was retained throughout the vegetative and reproductive phase of growth of pearl millet genotypes tested.

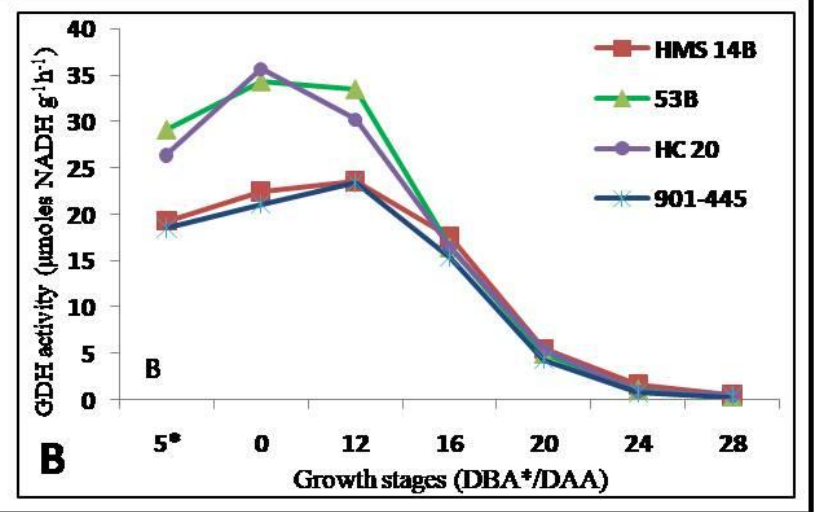

Fig 3. Glutamate dehydrogenase (GDH) activity ( $\mu$ moles $N A D H ~ ~ g^{-1} h^{-1}$ ) in flag leaf of pearl millet grain filling stages A. Flag Leaf B. Roots.

Table 6. Glutamate Dehydrogenase (GDH) activity ( $\mu$ mole NADH g ${ }^{-1} h^{-1}$ ) in roots of pearl millet at different growth stages

\begin{tabular}{ccccc}
\hline Grow & HMS & HMS & HC & WHC \\
\hline $\mathbf{5}$ & 19.25 & 29.1 & 26.4 & 18.5 \\
$\mathbf{0}$ & 22.35 & 34.3 & 35.6 & 21.1 \\
$\mathbf{1 2}$ & 23.52 & 33.45 & 30.2 & 23.45 \\
$\mathbf{1 6}$ & 17.48 & 16.39 & 16.3 & 15.36 \\
$\mathbf{2 0}$ & 5.47 & 4.96 & 5.33 & 4.29 \\
$\mathbf{2 4}$ & 1.66 & 1.09 & 0.86 & 0.76 \\
$\mathbf{2 5}$ & 0.52 & 0.33 & 0.45 & 0.27 \\
\hline
\end{tabular}

Aspartate aminotransferase (AspAT)

Qualitative and quantitative pattern of change in the level of activity of Aspartate aminotransferase in flag leaf and roots of the four genotypes is presented in figures 4 \& table $7 \& 8$. AspAT activity in flag leaf exhibited a profile similar to that of GDH activity in the respective tissues of the plant except that peak AspAT activity was detected at the onset of reproductive period i.e. 0 DAA instead of 12 DAA (Fig. 4). On 0 DAA flag leaf of HC 20 had maximum AspAT activity

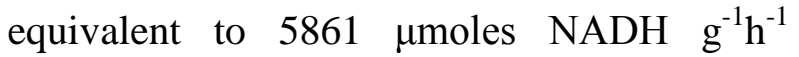
followed by HMS 14B $(5677 \mu$ moles NADH $\left.\mathrm{g}^{-1} \mathrm{~h}^{-1}\right)$, HMS 53B $\left(4884 \mu\right.$ moles NADH g $\left.{ }^{-1} \mathrm{~h}^{-1}\right)$ and WHC 901-445 (4512 $\mu$ moles NADH g ${ }^{-1} \mathrm{~h}^{-}$ $\left.{ }^{1}\right)$. Similar to GDH, a higher level of activity of AspAT was maintained during the period since flowering till physiological maturity of the grain compared to that recorded on 25 DBA. 

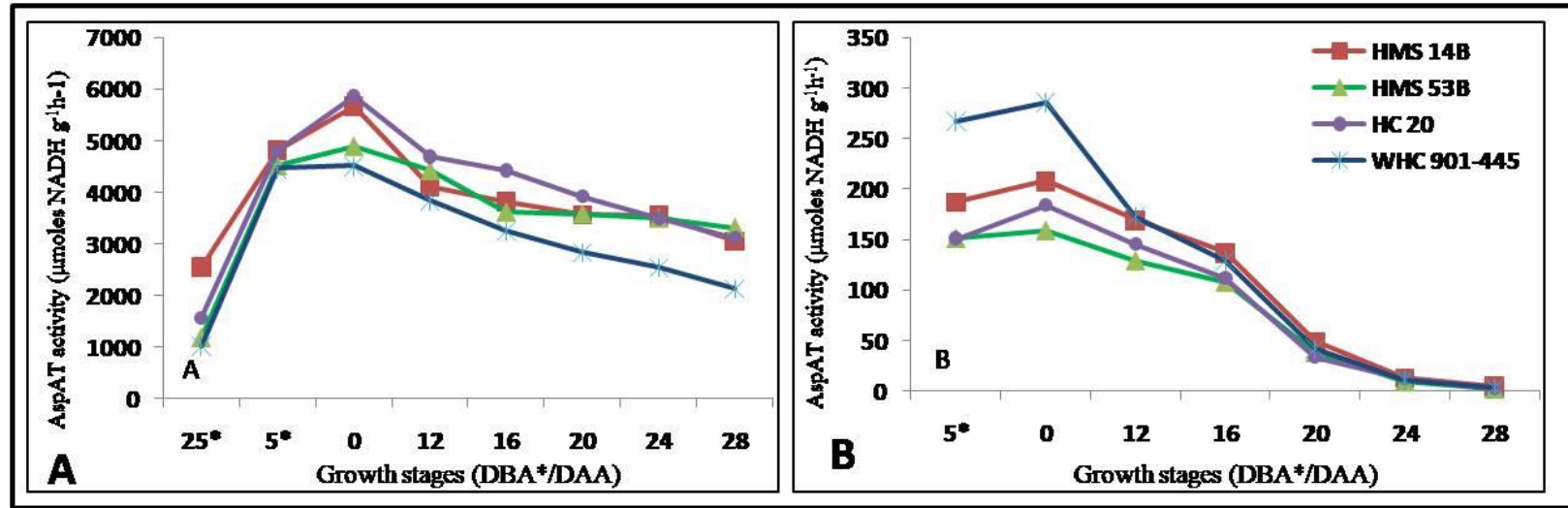

Fig 4. Aspartate aminotransferase (AspAT) activity ( $\mu$ moles NADH g $\left.{ }^{-1} h^{-1}\right)$ in flag leaf of pearl millet grain filling stages A. Flag Leaf B. Roots

Table 7. Aspartate aminotransferase (AspAT) activity ( $\mu$ moles NADH $\mathrm{g}^{-1} \mathrm{~h}^{-1}$ ) in flag leaf of pearl millet at different growth stages

\begin{tabular}{ccccc}
\hline Grow & HMS & HMS & HC & WHC \\
\hline 25 & 2554 & 1188 & 1582 & 1017 \\
5 & 4817 & 4514 & 4806 & 4462 \\
0 & 5677 & 4884 & 5861 & 4512 \\
12 & 4119 & 4415 & 4686 & 3835 \\
16 & 3828 & 3617 & 4429 & 3247 \\
20 & 3571 & 3581 & 3927 & 2838 \\
24 & 3557 & 3503 & 3498 & 2544 \\
25 & 3056 & 3313 & 3122 & 2128 \\
\hline
\end{tabular}

Table 8. Aspartate aminotransferase (AspAT) activity $\left(\mu\right.$ moles NADH $\left.\mathrm{g}^{-1} \mathrm{~h}^{-1}\right)$ in roots of pearl millet at different growth stages

\begin{tabular}{ccccc}
\hline Grow & HMS & HMS & HC & WHC \\
\hline 5 & 187 & 151 & 151 & 267 \\
0 & 208 & 159 & 184 & 286 \\
12 & 169 & 129 & 146 & 173 \\
16 & 137 & 108 & 112 & 129 \\
20 & 49 & 38 & 34 & 42 \\
24 & 13 & 9 & 12 & 11 \\
28 & 4.8 & 1.68 & 2.6 & 3.57 \\
\hline \multicolumn{5}{c}{ Even at 28 DAA substantial amount of }
\end{tabular}

activity of the enzyme (between 2000 to 3300 $\mu$ moles NADH $\mathrm{g}^{-1} \mathrm{~h}^{-1}$ ) in flag leaf of the tested genotypes was still present. Compared to flag leaf, activity of AspAT was very low in root tissues (Fig.4B \& Table 8). For example on 0
DAA activity of this enzyme in leaf of the respective genotype was at least 20 times higher than that present in roots. Compared to the other enzymes viz. NR, GS and GDH the difference in terms of folds in activity of this enzyme in leaf and root tissues was the highest. In contrast to flag leaf, AspAT in roots decreased sharply between 0 and 28 DAA. Among the designated B-lines maximum NR activity was present in the leaf of HMS HMS 14B (13.9 $\mu$ moles $\left.\mathrm{NO}_{2}^{-} \mathrm{g}^{-1} \mathrm{~h}^{-1}\right)$ followed by HMS 53B (7.16 $\mu$ moles $\mathrm{NO}_{2}^{-} \mathrm{g}^{-}$ $\left.{ }^{1} \mathrm{~h}^{-1}\right)$. Flag leaf of the composites showed in vivo NR activity closer to that of HMS 53B. The enzyme activity increased linearly in all the four genotypes till 0 DAA and reached at maximum level. After the start of anthesis activity of NR started declining in the remaining four genotypes, while in roots, NR activity continuously declined starting 5 DBA till maturity i.e. 28 DAA. Like flag leaf, in roots magnitude of NR activity of HMS 14B was higher while that of HMS 53B was lowest and other genotypes were more or less similar in respect of the level of activity. These results are corresponded with the earlier published 
reports. Wu et al. (2013), reported that NR activity in flag leaf of winter wheat peaked at 5DAA (Days after anthesis), decreased slowly until 15DAA and then dropped sharply under all irrigation and fertilizers treatments along with control. Liyuan \& Shi (2013) reported in winter wheat that nitrate reductase activity was very high at the beginning of the anthesis in flag leaf and continued to decrease till $7^{\text {th }}$ day after anthesis and decreased rapidly by $14^{\text {th }}$ day after anthesis. Raimanova and Trckova, (2007) reported maximum NR activity in wheat flag leaf at flowering stages and decreased until 25 DAF. Similar results for flag leaf NR activity were also observed in finger millet by Gupta et al. (2012) and in maize by Narasimhan et al. (1987). No such reports are available on pearl millet in the literature. GS activity of the tested genotypes differed markedly. GS activity was maximum in HMS 14B. Like NR, activity of this enzyme on the same day of plant growth in HMS 53B was lowest among the other genotypes. Activity of GS increased sharply along with growth of the plants till start of anthesis in each genotype but differentially and attained maximum level in each genotype. GDH activity in flag leaf showed increasing trend during vegetative stage starting 25 DBA till start of anthesis i.e. 0 DAA and in roots starting 5 DBA till 0 DAA. In general, level of GDH activity in flag leaf assayed on a particular day during the period between 0 and 20 DAA of HMS 14B, HMS 53B, HC 20 and WHC 901-445 remained either almost constant or decreased slightly. After slow and gradual decrease in activity of the enzyme after 20 DAA, a substantial amount of enzyme remained active on $28 \mathrm{DAA}$. These results for
GS and GDH enzyme activities are correspond with the earlier reports in wheat, rice and finger millets. Wu et al. (2013) reported that GS activity in flag leaf of winter wheat peaked at 5DAA (Days after anthesis), decreased slowly until 20DAA and then dropped sharply under all treatments along with control. Yong-Jian et al. (2009) had observed in rice flag leaf that GS activity increased from tillering stage to heading stages and started decreasing towards maturity stage at all irrigation and nitrogen fertilizer treatments. Liyuan \& Shi (2013) reported in winter wheat that GS activity in flag leaf was very high at the beginning of the anthesis in flag leaf. However flag leaf GS activity continued to decrease in 7 days after anthesis and decreased rapidly after 21 days after anthesis under all treatments and also reported that flag leaf GS activities increased with increasing amount of nitrogen application. It indicated that nitrogen fertilization improves the leaf NR and GS activity as well as leaf soluble protein content. Kichey et al. (2005) also observed similar results for GS and GDH with ageing flag leaf of wheat. Ino-kuchi \& Okada (2001) reported that GDH functions in the de-aminating direction in tissues (germinating seeds and senescing leaves) that are converting amino acids into transport compounds with a low $\mathrm{C} / \mathrm{N}$ ratio. Srivastava \& Singh (1987) reported that GDH level increased under various stressed conditions because plant may well need to give priority to carbon metabolism and keto-acid production over nitrogen metabolism. Gupta et al. (2012) had studied the relationship of nitrogen use efficiency with nitrogen metabolizing enzymes involved in nitrogen 
uptake and assimilation in finger millet under different nitrogen inputs and observed that sequential increase in the activity of GS and GDH during flowering and grain filling stages, respectively, in white and golden genotypes quickly transported the nitrogen from early stages of grain filling which continued till the end of grain filling. Both high GS activity along with high GDH activity is probably necessary at the time of flowering to grain filling to carry out the de-amination and trans-amination reactions during hydrolysis of flag leaf chloroplast initiated at the time of flowering. It also indicated that not only high GDH activity but also high activity of GS in the flag leaves at the time of grain filling is necessary to achieve higher grain protein content. No such reports are available on pearl millet. AspAT activity in flag leaf exhibited a profile similar to that of GDH activity in the respective tissues of the plant except that peak AspAT activity was detected at the onset of reproductive period i.e. $0 \mathrm{DAA}$ instead of 12 DAA. AspAT activity in flag leaf increases sharply till anthesis and reached to maximum and then started to decrease at a slower rate and was maintained more activity than its initial activity till maturity i.e. 28DAA. Before anthesis HMS 14B showed maximum activity but at anthesis HC 20 showed maximum activity in flag leaf. While in root at initial stage WHC 901-445 showed maximum activity. There was a little variation for AspAT activity among genotypes till 12DAA only after that all genotypes showed almost similar activity with sharply decreasing trend and reached to non detectable level at 24DAA.

\section{References}

Aubert S, Bligny R, Douce R, Gout E, Ratcliffe RG \& Roberts JKM. 2001. Contribution of glutamate dehydrogenase to mitochondrial glutamate metabolism studied by $\mathrm{C}-13$ and P-31 nuclear magnetic resonance. Journal of Experimental Botany, 52:3745.

Bergareche C \& Simon E. 1988. Nitrate reductase activity and nitrate content under two forms and three levels of nitrogen nutrition in Lolium perenne $\mathrm{L}$. Journal of Plant Physiology, 132: 28-33.

Berwal MK, Goyal P \& Chugh LK. 2018. Exploitation of pearl millet germplasm for identification of low grain phytate containing parental line. Journal of Agriculture and Ecology, 6: 39-46.

Claussen W \& Lenz F. 1999. Effect of ammonium or nitrate nutrition on net photosynthesis, growth, and activity of enzymes nitrate reductase and glutamine synthetase in blueberry, raspberry and strawberry. Plant \& Soil, 208: 95-102.

Cruz JL, Mosquim PR, Pelcani CR, Araujo WL \& Da Matta FM. 2004. Effects of nitrate nutrition on nitrogen metabolism in cassava. Biologia plantarum, 48: 6772.

Distelfeld A, Cakmak I, Paleg Z, Ozturk L, Yazici AM, Bodak H, Saranga Y \& Fahima T. 2007. Multiple QTL-effects of wheat Gpc-B1 locus on grain protein and micronutrient concentrations. Physiologia plantarum, 129 (3):635-643. https://doi.org/10.1111/j.13993054.2006.00841.x

Duffield RD, Croy LI \& Smith EL. 1972. Inheritance of nitrate reductase activity, grain protein and straw protein in a hard red winter wheat cross. Agronomy Journal, 64: 249. 
Fentem PA, Lea PJ \& Stewart GR. 1983. Ammonia assimilation in the roots of nitrate- and ammonia- grown Hordeum vulgare (cv. Golden Promise). Plant Physiology, 71: 496-501.

Fewson CA \& Nicholas. 1961. Nitrate reductase from Pseudomonas aeruginosa. Biochem Biophys Acta, 49: 335-349.

Goyal P, Berwal MK, Praduman \& Chugh LK. 2017. Peroxidase actvity, its isozymes and deterioration of pearl millet [Pennisetum glaucum (L.) R. BR.] flour during storage. Journal of Agriculture and Ecology, 3: 42-51.

Gupta N, Gupta AK, Gaur VS \& Kumar A. 2012. Relationship of nitrogen use efficiency with the activities of enzymes involved in nitrogen uptake and assimilation of finger millet genotypes grown under different nitrogen inputs. The Scientific World Journal, doi:10.1100/2012/625731.

Ingle J, Joy KW \& Hagemn RH. 1966. The regulation of activity of enzymes involved in the assimilation of nitrate by higher plants. Biochemistry Journal, 100: 577.

Inokuchi R \& Okada M. 2001. Physiological adaptations of glutamate dehydrogenase isozyme activities and other nitrogenassimilating enzymes in the macro- alga Bryopsis maxima. Plant Science, 161: 35-43.

Kanamori T, \& Matsumoto H. 1972. Glutamine Synthetase from rice plant roots. Archieves of Biochemistry Biophysics, 152: 404-412.

Kannangara CG \& Woolhouse HW. 1967. The role of carbon dioxide, light and nitrate in the synthesis and degradation of nitrate reductase in lines of Perilla fructescens. New Phytology, 66: 553.
Kichey T, Gouis JL, Brigitte S, Hirel B \& Duboise F. 2005. Change in the cellular and subcellular localization of glutamine synthetase and glutamate dehydrogenase durin flag leaf senescence in wheat (Triticum aestivul L.). Plant Cell Physiology, 46(6):964-974.

Lea PJ \& Miflin BJ. 1974: Alternative route for nitrogen assimilation in higher plants. Nature, 251:614-616.

Liyuan Y \& Shi Y. 2013. Effect of Nitrogen Application Rate on the enzyme activity of flag leaf agter anthesis in winter wheat. Advance Journal of Food Science and Technology, 5(6): 738-742.

Magalhaes JR, Grace PJ \& Rich D. 1990. Kinetics of ${ }^{15} \mathrm{NH}_{4}^{+}$assimilation in Zae mays. Plant Physiology, 94: 647-656.

Melo-Oliveira R, Oliveira IC \& Coruzzi G. 1996. Arabidopsis mutant analysis and gene regulation define a non-redundant role for glutamate dehydrogenase in nitrogen assimilation. Proceedings of the National Academy of Science USA, 93: 4718-4723.

Miflin BJ, Habash DZ. 2002. The role of glutamine synthetase and glutamate dehydrogenase in nitrogen assimilation and possibilities for improvement in the nitrogen utilization of crops. Journal of Experimental Botany, 53:979-987. doi:10.1093/jexbot/53.370.979.

Murray DR \& Kennedy IR. 1980. Change in the activities of enzymes of nitrogen metabolism in seed coat and cotyledon during embryo development in pea seeds. Plant Physiology, 66: 782-786.

Narasimhan C, Johari RP \& Mehta SL. 1987. Nitrogen assimilation in opaque \& normal sorghum during grain development. Journal of Biosciences, 12: 303-310.

Pryor A. 1990. A maize glutamic dehydrogenase null mutant is cold 
temperature sensitive. Maydica, 35: 367372.

Raimanova I \& Trckova M. 2007. Remobilization of nitrogen for wheat grain formation as affected by temperature \& drought. Bioclimatology \& Natural Hazard, Total Pages 6. (page no. note given). ISBN 978-80-228-1760-8.

Sawhney SK \& Naik MS. 1972. Role of light in synthesis of Nitrate reductase and Nitrite reductase in rice seedling. Biochemistry Journal, 130: 475-485.

Sempruch C, Leszczynski B, Chrzanowski G, Filipczuk A, Czerniewicz P \& Wolska K. 2012. Activity of aspartate aminotransferase and alanine aminotransferase with in winter triticale seedlings infested by grain aphid. Journal of Plant Protection Research, 52 (3): 364-367.

Srivastava HS \& Singh RP. 1987. Role of regulation of L-glutamate dehydrogenase activity in higher plants. Phytochemistry, 26: 597-610.

Stewart GR \& Larher F. 1980. Accumulation of amino acids and related compounds in relation to environmental stress. In "The Biochwemistry of Plants" (BJ Miflin ed.), Academic Press, New York, 5: 609635.

Stewart GR, Shatilov VR., Turnbull, M.H., Robinson, S.A. and Goodall, R. (1995). Evidence that glutamate-dehydrogenase plays a role in the oxidative deamination of glutamate in seedlings of Zea mays.
Australian Journal of Plant Physiology, 22: 805-809.

Streeter JG \& Thompson JF. 1972. Anaerobic accumulation of gamma-aminobutyric acid and alanine in radish leaves (Raphanus sativus L.). Plant physiology, 49:572-578.

Torre FDL, Canas RA, Pascual MB, Avila C \& Canovas FM. 2014. Plastidic aspartate aminotransferase and the biosynthesis of essential amino acids in plants. Journal of Experimental Botany, 65(19): 55275534. Doi: 10.1093/jxb/eru240.

Wu JD, Li JC, Wang CY, Wei FZ, Zhang Y \& $\mathrm{Wu}$ WM. 2013. Effects of spraying foliar nitrogen on activities of key regulatory enzymes involved in protein formation in winter wheat suffered postanthesis high temperature and waterlogging. Journal of Food Agriculture \& Environment, 11(2):668-673.

Yong-Jian S, Yuan-Yuan S, Xu-Yi L, Xiang G \& Jun M. 2009. Relationship of nitrogen utilization \& activities of key enzymes involved in nitrogen metabolism in rice under water-nitrogen interaction. Acta Agronomica Sinica, 35(11): 2055-2063.

Yong-Jian S, Yuan-Yuan S, Xu-Yi L, Xiang G \& Jun M. 2009. Relationship of nitrogen utilization and activities of key enzymes involved in nitrogen metabolism in rice under water-nitrogen interaction. Acta Agronomica Sinica, 35(11): 2055-2063. 